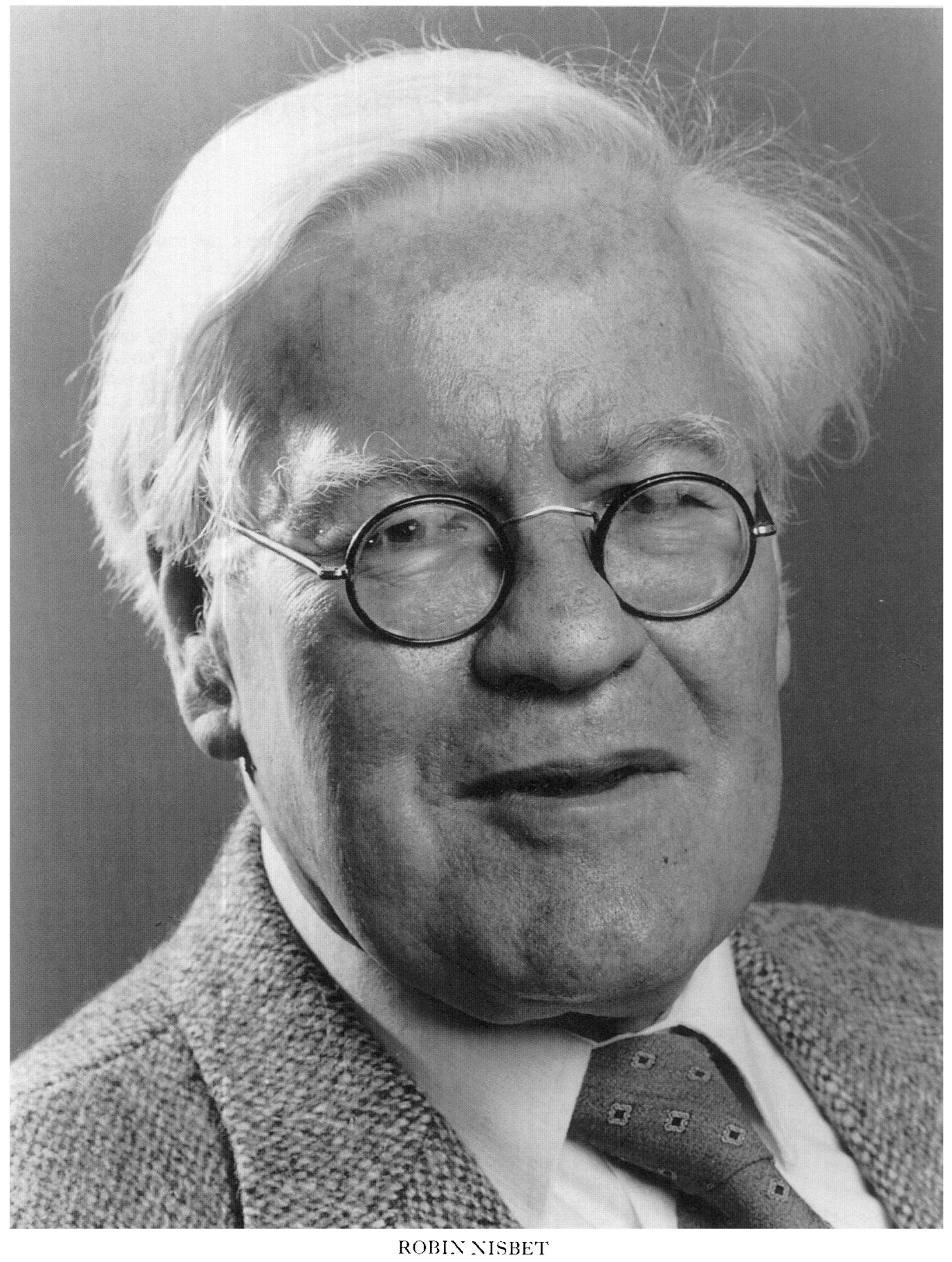




\section{ROBIN NISBET}

\section{5 on 2 I May 2000}

For the Fournal of Roman Studies Robin wrote in 1955 one of his first reviews and in 1958 his first article. From 1976 to 1985 he served on its editorial board, and since 1972 he has been a Vice-President of the Society. In the Society and among readers of Latin literature everywhere, his 75 th birthday calls for capaciores scyphos.

'At the beginning of the century', he wrote in 1987, 'cultivated English scholars, repelled by the schematism of more analytic minds, . . made sardonic asides about "the Higher Criticism", and in so doing cramped the study of ancient literature in this country for a generation'. Generations are slippery things, and he has not said when the study of Latin literature began to stretch its legs; but his own modestly titled 'Notes on Horace, Epistles I' of I 959 now looks like such a moment. Horace entrusts to one Vinnius the delicate task of delivering a volume to Augustus; by identifying Vinnius with a noted weightlifter in Augustus' bodyguard, Robin in one page changed the poem and invited a fresh approach to the collection. Names and lives, often in a setting of political history, have run through much of his work.

In other hands, a commentary on In Pisonem, despite historical flair and first use of an important witness, might have seemed unadventurous in 196 I after his father's on De domo and the third edition of Roland Austin's on Pro Caelio, but the broader scene that opens out in several of the appendices, together with an exploitation of clausulae that was rare at the time, has kept Robin's first book in the front rank as a commentary not limited to the words of the text, and it still makes a powerful impression with its forthright judgements, quiet wit, and mastery of perspective ('it is important to learn' from Catullus 28 'that Piso restricted the depredations of his staff'). The same mastery of perspective guided his Livian reading of the Aeneid in I980, 'Aeneas imperator', and brought it to a Stoic conclusion worthy of Virgil's: 'The imperator wins his spolia opima from Turnus, but the supreme command has eluded him: "imperare sibi maximum imperium est"' (Sen. Epist. I I 3.30)'.

What belongs to Robin, what to Margaret, in the great commentary of Nisbet \& Hubbard on Horace's Odes, of which the first volume appeared in I 970 and the second in 1978 , has been a closely kept secret, and what spurred him only emerged in 1989 : "it is a good idea to write commentaries as one's own notes are easier to remember than other people's'. The second volume fell in a period of astonishing productivity that added two feathers to the cap of the fournal: the editio princeps of the Gallus papyrus, and 'Felicitas at Surrentum (Statius, Silvae 2.2)'. Pending the verdict of posterity on the article that best displays Robin's varied talents (and who knows what will accrue round the edges of the forthcoming commentary on Odes 3 by Nisbet $\&$ Rudd?), here is a vote for 'Felicitas'. From Epicurean imagery to patronage, social status, remarriage, declamation, epigram, the arrangement of Silvae 2, the style of the Annaei, and the seductive strains of Sirens, hardly a sentence passes without a crisp argument or enriched understanding, and a succession of plausible identifications turns Argentaria Polla, widow of Lucan and wife of Pollius Felix, into 'a clearing-house for some of the literary currency of the Silver Age'. This piece and even more one of his latest, 'The survivors: old-style literary men in the triumviral period', recall the manner of Ronald Syme, whose work has inspired him more than anyone else's; and Syme would have applauded the historical reasoning in an article of 1990 , 'The dating of Seneca's tragedies'.

If Syme had a rival as an inspiration to Robin, it would be Housman, penetratingly assessed in an article of 1989 , 'On Housman's fuvenal'; but Paul Maas remarked that every problem of textual criticism is fundamentally a problem of style, and Robin's eye for style, certainly over his chosen range of central authors, may be thought to surpass Housman's. In reviews and articles he has restored logical and stylistic coherence to one passage after another of Cicero, Catullus, Horace, Petronius, Juvenal. After hitting 
upon his elegant idea at Lucan 9. $5_{5} 8$, transmitted as evolvam busto iam numen gentibus Isim, he might well have quoted the one line and said nothing more than 'No-one can be "unwrapped" from a tomb: read bysso'; but he set the conjecture in a commentary on twelve lines, 'Sacrilege in Egypt', where amongst other things he brought out the colours lent to the speaker, $\mathrm{Cn}$. Pompeius, by the Herodotean Cambyses. Catullus 22.6 and Silvae 4.3.5 I are two more passages where he has scored a bull's-eye with latinized Greek (bibli for libri, scolopas for scopulos), and his first-hand acquaintance with a wide range of Greek literature has enlivened many of his observations.

Rather than a literary critic, Robin would call himself a literary historian, but much of his own work, for instance the fine appreciation of Persius that he wrote in 1963 for John Sullivan, makes the distinction even harder to sustain, and over the years, as he acknowledges, he has pushed out his boundaries, above all by being readier to look for connotations beyond primary meaning. Fruitful exchanges in seminars and supervisions have contributed. Occasional attempts at drawing a sharp line for the good of the subject have not prevented him from encouraging young scholars of the most diverse temperaments, and he has to his name a long line of distinguished pupils, all devoted to him. A charge of 'waffle' from one of them brings a response in good part, and it is easy to picture the embarrassed frown dissolving into an almost conspiratorial chuckle. The two things that seem to have disturbed him most are of a quite different kind: a curmudgeonly review of a commentary by a former pupil, and Jasper Griffin's protest that in the commentary on Horace literary convention too often drives out social realities. What, weak on reality Nisbet, that devotee not just of Roman but of modern history ('one recalls Lord Cardigan's yacht at Balaclava'), who has grasped 'the sense of the possible that made the Roman empire last longer than some others'? Needless to say, he replied with scrupulous fairness, and honours were split; perhaps he even won on jokes ("when the belated diner-out hurried along the Subura in the rain, did he really pick his way over the prostrate forms of the major Augustan poets?').

Deeply respected, too, is the element of unpredictability that goes with openness of mind and independence of judgement. He has made no secret of his vacillations over Hercules Oetaeus, and his deletions in Juvenal have not affected his views on the Helen episode in the Aeneid. One of his latest articles, 'Adolescens puer' of I 993, which begins with a characteristically astringent sentence ("In the Liverpool Classical Monthly Dr John Pinsent has enabled scholars to air their theories before others could think of them or they themselves repent of them') and continues with another ('Among many other services he has found space for notes on the sexual language of antiquity, when they might have impaired the stylistic unity of primmer journals'), uncovers male genitals in apocalyptic lines of the fourth Eclogue.

In the 2000th year after Horace's death, when Robin retired from his chair, admirers of both gathered at Corpus to congratulate them on their association. For Robin's 7oth birthday in 1995 , the written record of the event, Homage to Horace, was accompanied into print by his Collected Papers on Latin Literature, which ends with a bibliography. At the next opportunity, the British Academy in a citation of unusual warmth bestowed on him its Kenyon Medal for Classical Studies.

On the last page of the Collected Papers, Robin commends to his audience three quotations, of which 'the first is a famous dictum of Epicharmus, indeed it is the only famous dictum of Epicharmus ... : "Keep sober, and remember to disbelieve"'. We had better not try to budge him from 'Keep sober'; but if 'Remember to disbelieve' is an instruction for reading Robin himself, we shall drown it in cold water. Long may he continue to enlighten us!

M.D.R. 